\title{
Mapping of the dilemma of mining against forest and conservation in the Lom and Djérem Division, Cameroon
}

\author{
Tchindjang Mesmin, ${ }^{a}$ Voundi Eric, ${ }^{b}$ Mbevo Fendoung Philippes, ${ }^{b}$ Haman Unusa, ${ }^{c}$ Saha Frédéric ${ }^{b}$ \\ and Njombissie Petcheu Igor Casimir ${ }^{\mathrm{b}}$ \\ ${ }^{a}$ University of Yaoundé Imtchind@yahoo.fr,Tchindjang.mesmin@gmail.com \\ ${ }^{b}$ Global Mapping and Environmental Monitoring eric.voundi@yahoo.fr,fredericsaha@yahoo.fr,petcheul@yahoo.fr \\ ${ }^{c}$ Ministry of Environment, Protection of Nature and Sustainable Development hamanunusa@yahoo.fr
}

\begin{abstract}
Mining practices in Cameroon began since the colonial period. The artisanal mining sector before independence contributed to $11-20 \%$ of GDP. From 2000, the rich potential of the Cameroonian subsoil attract many foreign investors with over 600 research and mining permits already granted during the last decade. But, Cameroonian forests also have a long history from the colonial period to the pre-sent. However, mining activities in forest environments are governed by two different legal frameworks, including mining code i.e. Law No. 001 of 16 April 2001 organizing the mining industry and Law No. 94-01 of 20 January 1994 governing forests, wildlife and fisheries. Therefore, in the absence of detailed studies of these laws, there are conflicts of interests, rights and obligations that overlap, requiring research needs and taking appropriate decisions. The objective of this research in the Lom and Djérem division is to study, apart from the proliferation of mining li-censes and actors, the dilemma as well as the impact of the extension of mining activities on the degradation of forest cover. Using geospatial tools through multitemporal and multisensor satellite images (Landsat from 1976 to 2015, IKONOS, GEOEYE, Google Earth) coupled with field investigations; we mapped the dynamic of different forms of land use (mining permits, FMU and protected areas of permanent forest estate) and highlighted paradoxically the conflict of land use. We came to the conclusion that the rhythm of issuing mining permits and authorizations in this forestall zone is so fast that one can wonder whether we still find a patch of forest within 50 years.
\end{abstract}

Keywords: Bétaré-Oya, deforestation, gold, Lom \& Djérem, mining

\section{Introduction}

Mining international context is characterized by a strong demand for minerals like gold, aluminum, cobalt, iron, diamond, etc. The provision of these is difficult to satisfy, due to political instability in the major producing countries (South Africa, Congo DRC, India, Central African Republic, etc.). It rose up a dramatic rise in prices. As Cameroon is concerned, the mining sector only accounts for $1 \%$ of Cameroon's GDP because of trafficking, misappropriation of production or poor governance. It should also be noted that the highly lucrative character of mining involves a preference for this activity at the expense of the sustainable management of communal and state forests.

Mining, which was very old in Cameroon, remained artisanal and marginal until the beginning of the 1990s, the date of the first attempts to organize the sector by the various actors. However, the mining circuit in Cameroon remains complex; both in terms of legal operating procedures and government statistics as well as in terms of production and especially the number of operators. In addition, this sec-tor currently has two faces, a craft sector strongly implanted and in full effervescence, a modern sector that is still embryonic. In artisanal mining, it is estimated that more than 15,000 people are involved in this activity on a full-time basis. The government's efforts to organize this activity have resulted in the creation of the CAPAM (Support Framework for Mining Crafts), whose tasks include: technical supervision of operators and channeling their production to formal frame-works. The modern sector, destined to develop within Cameroon's ambitions for development, aims to explore, exploit and transform deposits. The Eastern region, which is extremely rich in mineral resources, is subject to enormous greed from large operating companies. The same region is where industrial forestry concessions have been established the longest, resulting in conflicts and overlaps be-tween Forest Management Units (FMUs), protected areas and mining permits.

At the beginning of the 3rd millennium in Cameroon, mining is at the center of all issues and raises debates depending on whether one is an economist, a forester, an ecologist, an administrator or a conservator. Indeed, conservationists are seen as detractors whereas economists find a good source of income for the state and for the populations. To better understand this situation, we must start from the rapid spatial expansion of mining activity for about 15 years. Secondly, we must analyze the consequences of this development and the related controversies. In-deed, in the current literature, even in countries with a long tradition and experience in this field, social costs and environmental impacts are not always easily controlled. The role of remote sensing and GIS is crucial in this process, both in terms of quantitative assessment of the areas occupied and the 
land use in the areas of exploitation, but also in terms of ecological and socio-cultural impacts. Three main questions raised up: how to reconcile mines and conservation of the Lom and Djérem forestall massifs? How to combat poverty and land conflicts emanating from this activity? How to sustainably exploit existing mines and forests by avoiding conflicts of land use?

Among the assumptions arising from this problem, we can note:

- The unbridled and uncontrolled development of artisanal mines and the negligent granting of exploration or mining permits which have a considerable impact on ecosystem fragmentation, forest degradation and deforestation. In addition, extractivism mortgages conservation.

- This development could, in the absence of integrated activities (agriculture and livestock farming), jeopardize food security (abandonment of food speculation for mines), affect the health of minors, increase poverty and loss of identity of indigenous peoples Due to the disappearance of the forest patrimony of which they have long been dependent and guarantor). There is a lack of zoning and a resurgence of conflicts.

- The objective of this research in the Lom and Djérem is to study the environmental impact of the extension of mining activities on the degradation of forest cover outside of the multiplication of permits and actors. The assessment of this dynamics requires the superimposition of the various forms of land use (mining permits, FMUs and protected areas in the permanent forest domain) and the resulting conflicts over land use.

Specifically, the study will:

- draw up a typology of mining permits and authorizations in the Department of Lom and Djérem

- assess the impact of mining on degradation of forest cover in terms of degradation and reduction of forest area, loss of biodiversity, habitat fragmentation and impact on forest management;

- evaluate by diachronic mapping the forest dynamics linked to mining in terms of conversion of forest areas into mining fields through the clean cut of the forest and destruction of natural habitats;

- Studying the superimposition of mining permits and forest conservation areas; it is a question of evaluating by superimposed mapping the current status of the permits of exploitation and their geographical position in relation to the protected areas; Forests and forests.

The use of geospatial tools coupled with a careful field survey allowed us to monitor the evolution of permits and the development of these activities.

\section{Cameroon mining context}

With just over 17 million hectares of dense rainforests, Cameroon is one of the four main forestall countries of the Congo Basin (Wasseige 2008). Its forest area covers about $42 \%$ of the national territory. It has a fairly large and diverse ecological and floristic potential with more than 600 species, 300 of which can be marketed in the form of timber, of which only 60 are currently exploited (FAO 2005). It contains one of the richest and most varied fauna of the continent (FAO 2005, MINEF 1995, Eba'a Atyi et al., 2013).

The forestry sector remains an important source of revenue for the Cameroonian government. The Forest Law of 1994 amended in 2009 introduced a framework setting the benefits for local communities. In accordance with this law and subsequent regulations, $50 \%$ of the RFA goes to the treasury, $20 \%$ to the FEICOM, 20\% to the local council and $10 \%$ to the local communities.

As in the forestry sector, Cameroon is a country with diverse and unequally distributed extractive resources throughout its national territory and attractive to investors. Since the publication of the Investor-Friendly Mining Code of 16 April 2001, 167 exploration licenses and 5 mining permits have been issued for only $40 \%$ of the Cameroonian territory explored.

\section{Physical and human presentation of the Lom \& Djérem Division}

The target area studied is the Lom \& Djérem, one of the four administrative divisions of the Eastern Region of Cameroon. This division with 08 districts (Ga-roua Boulaï, Bétaré Oya, Bélabo, Diang, Bertoua 1, Bertoua 2, Mandjou, Ngoura), hosted the Bélabo council forest, the Kobungunda protection forest and two protected areas: Mbam \& Djerem and Deng-Deng National Parks. The East-ern Region of Cameroon covers an area of more than $109002 \mathrm{~km}^{2}$, which represented about $1 / 4$ of the Cameroon area. This region borders with the Central Afri-can Republic.

From a geomorphological point of view, the Lom \& Djérem is part of the South Cameroon plateau with an altitude ranging from 600 to $900 \mathrm{~m}$, built on geological formations rich in quartz, kaolinite, goethite and gibbsite. The entire land-scape lay on a Precambrian plateau belonging to the Mbalmayo-Bengbis series (Gartlan 1989). The soils are ferralitic red, clayish, soft and permeable with little humus. A dense hydrographic network drains the Lom \& Djérem. In fact, the two main rivers which form part of the Congo River basin throw themselves in the Sanaga.

The study area belongs to a warm and humid equatorial climate comprising 4 seasons; two rainy seasons that stretch from March to June and September to November, and two dry seasons from December to February and July to August. The average annual temperature is $24^{\circ} \mathrm{C}$ and annual rainfall is between $1,180 \mathrm{~mm}$ and 2,000 $\mathrm{mm}$. The annual thermal amplitude between the hottest and coldest months is $2^{\circ} \mathrm{C}$. Evapotranspiration is between 1,150 and $1,300 \mathrm{~mm}$ per year (Suchel, 1988). 
The vegetation of Lom \& Djérem is schematically broken down between the rain forest (most protected areas) and a forest-savanna mosaic (in the north). Within these two groups, there are different flora facies: semi-deciduous forests, secondary forests, gallery forests and swamp forests, grassy and wooded savannahs (Letouzey, 1985). The diversity of these habitats and the landscapes they make are potentially attractive to visitors. These ecosystems are all the more spectacular because they are crossed by large rivers (Lom, Pangar, Djérem and Sanaga rivers) with deep valleys, offering wide panoramas.

The forest is not only more preserved, but it is home of more "patrimonial" species; particularly the great apes (chimpanzees and gorillas). Other forest species likely to be encountered in the parks are: black colobus, bush pig, hylocherus, aquatic chevrotain, sitatunga, buffalo, etc. Although extensive inventories have not yet been carried out, avifauna, herpetofauna and entomofauna also seem to be of interest.

The Lom \& Djérem has a population of 275784 inhabitants, a density of 10.57 inhabitants per $\mathrm{km}^{2}$ which is one of the lowest in Cameroon. Populations tend to concentrate around urban centers, notably Bertoua and Bétaré Oya.

In this forest zone, climate and soil quality are favorable to subsistence farming (tubers, bananas, maize, etc.) and cash crops (robusta coffee, cocoa, palm, rubber, etc.). In the savannah zone, agriculture is mainly subsistence farming, which is a grazing area for herds and even transhumant coming from the more northerly regions. The Eastern Region is perceived as the Cameroonian El Dorado. The first attempts at mineral exploration date from the colonial period. Undoubtedly, gold is the first mineral discovered. From 1933 to 1942 , about $717 \mathrm{~kg}$ of this precious metal was pulled annually from the basement.

\section{Methodology}

Mining has become a very sensitive activity in the World and particularly in Cameroon at four levels: social, political, economic and environmental. Its social and environmental impacts are decried in many countries. It is for this reason that the methodology used has been broadly mixed and includes 5 complementary and integrated steps, including documentary research, acquisition of satellite imagery, image processing, qualitative field observations and participatory surveys, data treatment Survey and their integration and combination with GIS. The 10 Landsat images (MSS, TM, ETM +, Landsat 8) and SRTM images were downloaded from Maryland's GLCF site. They are staggered from 1976 to 2015. The 16 SPOT images were provided to us directly by the GEOST team during on June 16th, 2015. Finally, IKONOS (2 images) and GEOEYE (6 images) coming from Digital Globe were purchased from the authorized distributor GEOCOM. The Bé-taré-Oya Google Earth images were cut from the site and processed. If the Land-sat images were complete, the SPOT images did not cover the entire Lom \& Djérem.
In addition, we uploaded Google Earth images (10) that focus on Bétaré Oya and its outskirts as well as the Deng - Deng National Park. The Interactive Forest Atlas (version 3.0) was also consulted to view the permits before superimposing to other land use on GIS.

The processing and interpretation of the images thus acquired were organized in several stages and several integrated teams:

Pre-processing and application of filters to visualize and recognize targets. The difficulty here was the recognition of artisanal mining in the images. We were able to spot them along the rivers and a first team of 03 people was in charge of visualization and recognition. The opening and viewing of Google Earth images for different sectors has also been of great help, especially along the rivers, where gold extraction is alluvial.

A second team of 02 people worked on supervised image classification under ENVI 4.7 and ERDAS 2014. These classifications have enabled us to highlight dynamics and changes in land use; which we subsequently supplemented by fieldwork. In addition, the land cover area (Mosaic savanna forest, dense forests of high conservation value, secondary forest, savannahs, mines, etc.) was assessed. The layers thus obtained have been vectored and integrated into a GIS.

A third team of 02 people worked on ARCGIS10.0 and QGIS 2.8 digitization of very high resolution images (GEOEYE, IKONOS, and Google Earth). This has allowed not only to refine the areas but also to observe the attack of forest and forest conservation areas through artisanal mining. This has been very helpful in identifying land use conflicts.

The fourth team carried out the mosaicking of the treatments / classifications and the production of the synthesis maps by year on the land use dynamics in the Lom \& Djérem division under ARCGIS 10.0 and QGIS 2.8 after integration of the collected data coming from the field survey.

In addition, mining permits and other exploration permits collected during the field surveys were entered under Excel. This database has been integrated into the GIS and we have been able to compare the areas proposed by the mining authorities with those obtained from the GIS on the basis of the corresponding geographical coordinates. We have detected many errors in the allocation of mining permits and licenses in Cameroon. This allocation appears to be based on the maps 1: 200 000, which is subject to enormous misunderstandings, overlap and multiple conflicts.

\section{Results and interpretation}

The results are presented in two subsections. The first one will deal with the evolution of mining licenses while the second concerns, the mapping of the land use dynamics.

\subsection{Evolution of the mining permits}

On the basis of the permits and authorizations obtained from the Lom and Djérem Divisional Delegate of Mines, we have constructed charts (figures 1-2) which show the 
situation of the mining permits in eastern region since 2003 and Lom \& Djérem since 2003.

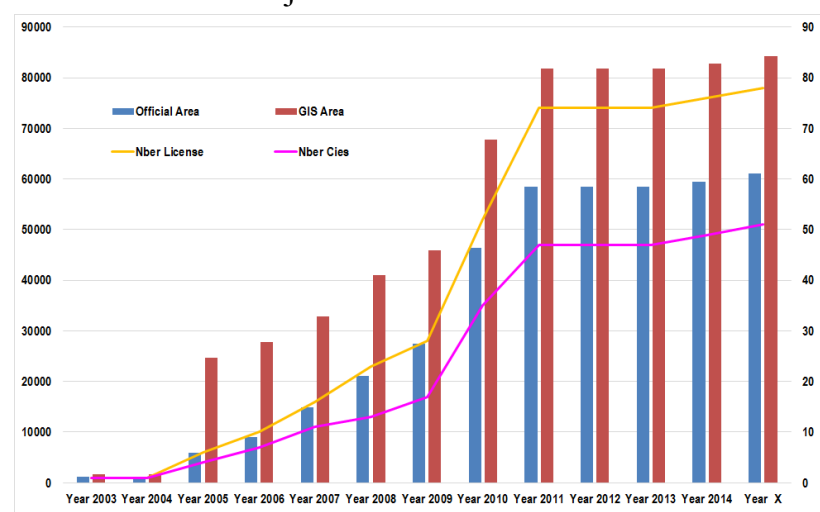

Fig. 1. Mining permits granted to the Eastern Region of Cameroon since 2003 (Field surveys 2015 and Tchindjang et al., 2015).

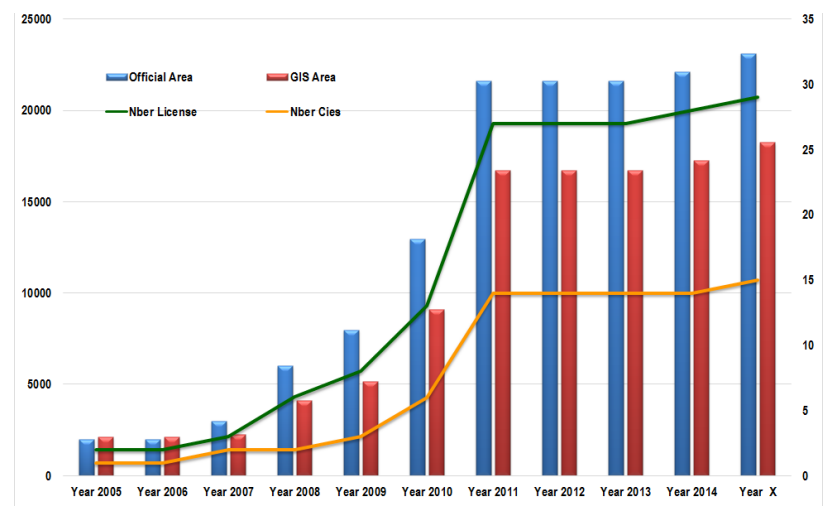

Fig. 2. Mining licenses granted to the Lom \& Djérem Division since 2005 (Field surveys 2015 and Tchindjang et al., 2015).

Compared to the rest of the territory, these licenses of exploration account for at least 70 to $80 \%$ of the Lom \& Djérem territory compared with $50-70 \%$ of the Eastern Region area. Of the 160 licenses granted in the whole country, half are from the Eastern Region and Lom \& Djérem has 29 licenses straddling it territory. We found that the official licenses granted do not always match with those obtained on GIS. The number of companies holding exploration permits increased from just one in 2003 to more than 40 companies in the Eastern Region (Fig 1) and 15 in Lom \& Djérem (Fig 2). Such a result shows the extent of land use in this area once known for its forest resources and which is currently experiencing difficulties in integrating the various activities on its soil; there is the dilemma.

\subsection{Land use dynamic mapping}

Land use maps were obtained after processing and classification of Landsat images. Figures 3-7 show these maps and it is curious to observe on filed survey that the exploration licenses become operating permits and it is difficult to distinguish them. In 1976, the forest covered more than $2 / 3$ of this territory (Fig 3 ).

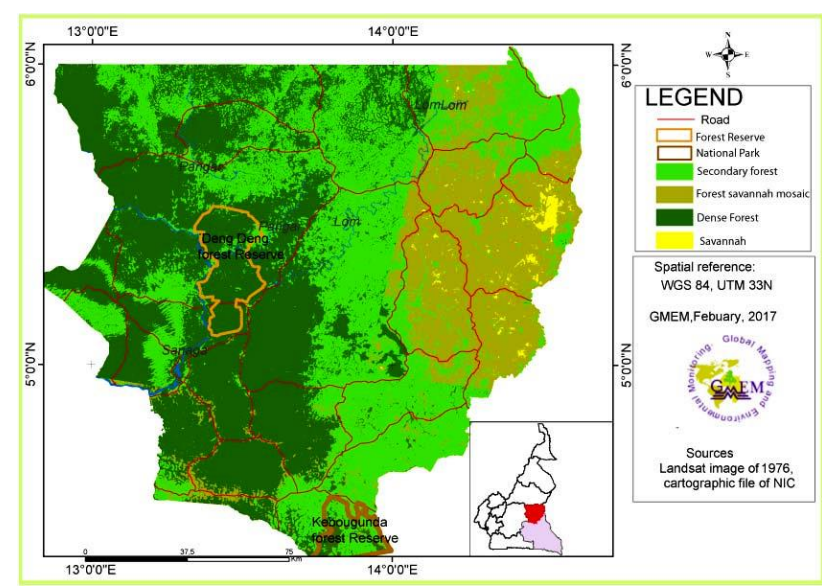

Fig. 3. Land use in the Lom \& Djérem in 1976 (Landsat MSS).

In 1976, the Lom \& Djérem hosted 4 types of vegetation: dense forest, secondary forest, forest-savannah mosaic and savannah. As conservation is concerned, there were 2 protected areas: the Kobungounda Forest Reserve and the Deng-Deng Reserve. The artisanal gold exploitation has not yet begun.

But in 1987, the Lom \& Djérem shows a noticeable change with the occurrence of artisanal mining, which proceed by exploring the valleys of rivers, including the Lom and Pangar rivers (Figure 4).

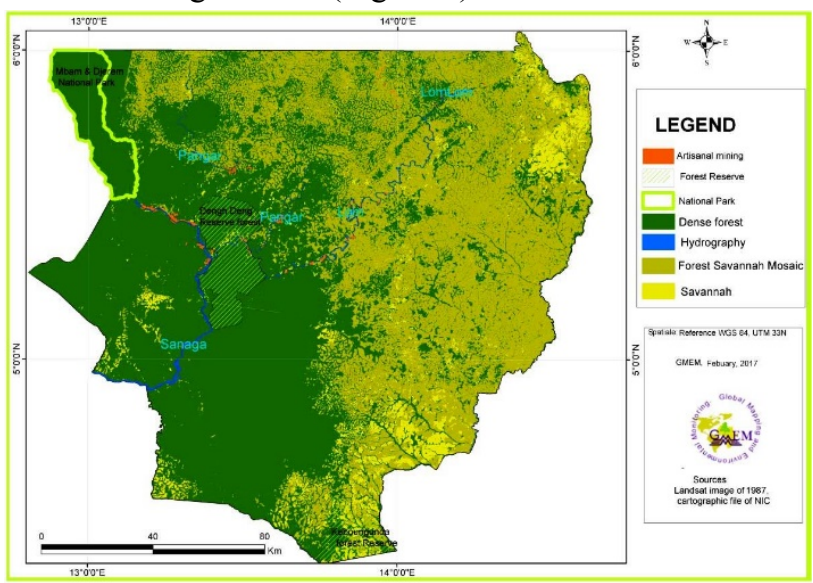

Fig. 4. Land use in the Lom \& Djérem in 1987 (Landsat TM).

However, the dilemma began at this area with is the forefront of the conservation in Cameroon. What is worrying is the disappearance of secondary forest in favor of the mosaic savannah forest and savannahs. As regards conservation, apart from the two previous reserves, the Mbam and Djérem National Park is added to these two protected areas.

In 2000, the situation has changed dramatically with an explosion of artisanal gold mining along the valleys of the main rivers (Fig.5). There are also some plots within the Sanaga valley at the Southwest of the Map. These incursions of artisanal exploitation can be observed even in the protected areas. In addition, the savannah seems to have retreated in favor of the forest-savannah mosaic. The Kobungounda Forest Reserve also appears to be threatened by the development of the Bertoua town. 


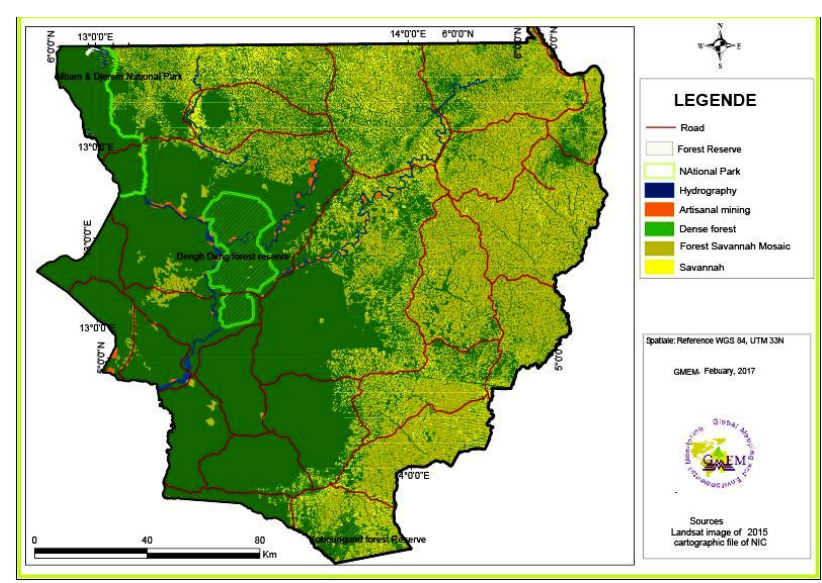

Fig. 5. Land use in the Lom \& Djérem in 2000 (Landsat ETM).

In 2010, the situation has worsen, because new land uses have been set up in Lom \& Djérem with council forests, community forests and forest management units (FMUs), as can be seen in fig 6 that shows some licenses granted.

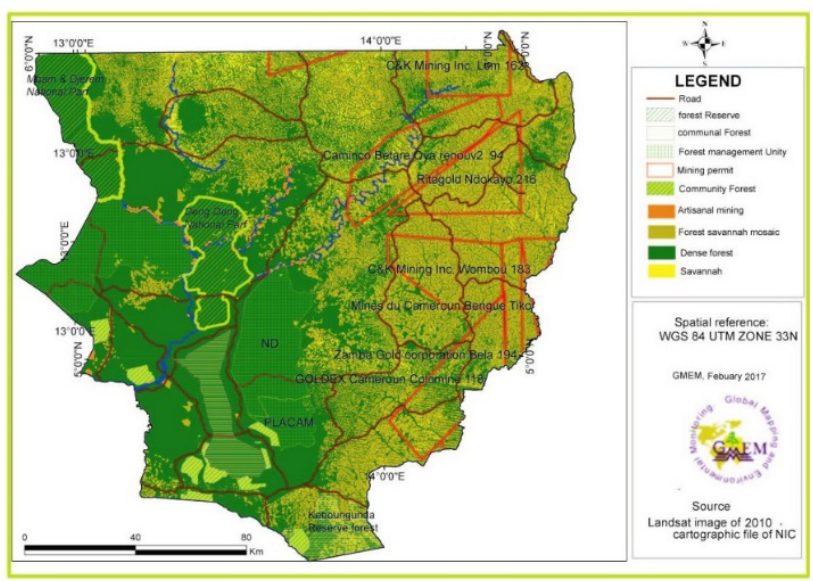

Fig. 6. Land use in the Lom \& Djérem in 2010 (Landsat 8).

Artisanal gold mining has been coupled with the granting of mining exploration permits and mining licenses since 2005. This includes the licenses of CK Mining, CAMINCO, Goldex Colomine and Zamba Gold. This situation will increase in 2015 and the first overlaps, mines-mines, UFA mines, mines - agriculture, mines communal forest, mines - community forest, mines other forms of land use (Fig. 7) .

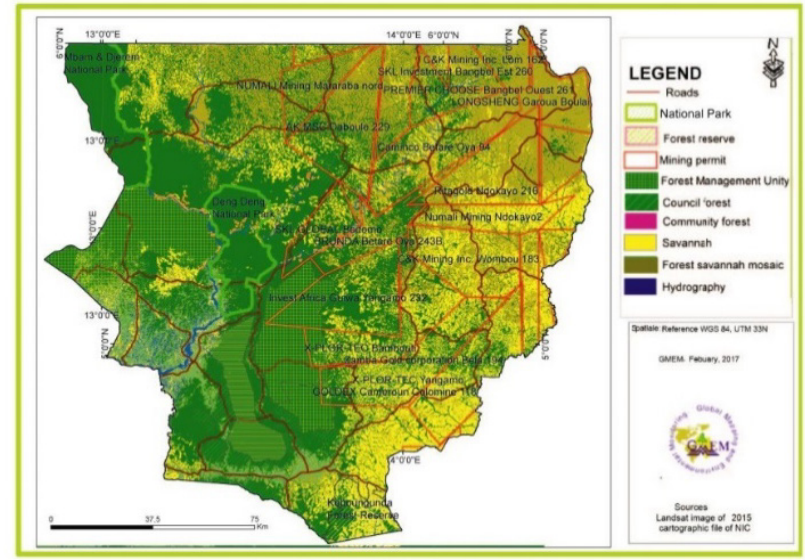

Fig.7. Land use in the Lom \& Djérem in 2015 (Landsat 8).
The incursions of artisanal exploitation will get intensifying in the Deng-Deng national park. The savannah areas have increased considerably while the forest is crumbling. There is therefore an intense deforestation which progresses from the Eastern part of the division towards its western part where the forest still seems relatively conserved. Table 1 summarizes this situation and shows a decline of at least $60 \%$ in the forest.

\begin{tabular}{l|c|c|c|c|c} 
Matter & $\begin{array}{r}1976- \\
1987 \\
\text { rate }\end{array}$ & $\begin{array}{r}1987- \\
2000 \text { rate }\end{array}$ & $\begin{array}{r}2000-2010 \\
\text { rate }\end{array}$ & $\begin{array}{r}2010-2015 \\
\text { rate }\end{array}$ & $\begin{array}{r}1976-2015 \\
\text { rate }\end{array}$ \\
\hline $\begin{array}{l}\text { Dense Forest } \\
\text { Forest - Savannah }\end{array}$ & $-32,09$ & $-40,50$ & $-13,32$ & 12,79 & $-60,50$ \\
Mosaic & 16,09 & 4,90 & $-29,01$ & 95,35 & 22,07 \\
$\quad$ Savannah & 401,90 & 381,73 & $-29,82$ & 105,50 & 3386,94 \\
Artisanal mining & - & 120,28 & 14,24 & 18,21 & 197,48 \\
Mining license & - & - & - & 2786,1 & 2786,15 \\
Community forest & - & - & - & 125,77 & 2333,03 \\
Council forest & - & - & - & 420,98 & 420,98 \\
Protected area & 0 & 0 & 89,64 & 0 & 865,53 \\
Hydrography & 38,88 & 99,86 & $-2,42$ & $-39,60$ & 63,58 \\
Bare soils and & 100 & 50 & 300 & 108,33 & 2400 \\
housing & & & &
\end{tabular}

(Source: Field work 2015 and Tchindjang et al. 2015)

Table 1. Deforestation and mining dynamics in the Lom \& Djérem

\section{Discussion}

The mining industry in Cameroon as well as in the Congo Basin is a dual sector that combines industrial mining operators with artisanal miners. Artisanal miners exploit deposits using rudimentary technologies for gold, diamonds and sapphires processing. Toxic chemicals are used in the artisanal gold mining (especially cyanide). Industrial operators generally use mechanized equipment to access deposits near the surface. The waste coming from these activities is thrown within the rivers water killing biological life.

The Lom \& Djérem is the northernmost part of the Eastern Region of Cameroon. It constitutes a hub of biological diversity, which has led to the creation or erection of some protected areas.

The Mbam and Djérem National Park (416512 ha) created in 2000 due to the decommissioning of PangarDjérem National Park (177480 ha) because of the DobaKribi Pipeline. Only the southern portion of this park appears in the Lom \& Djérem territory.

The Deng-Deng National Park created in 2010, replaced the former Deng-Deng Forest Reserve and increased its area to meet the challenges of deforestation and poaching. It is also close to the Mbam and Djérem National Park and forms a coherent network of protected areas that could be linked by an ecological corridor along the Djérem River. It is covered by dense rain forest, characterized by the presence of threatened primate species, including great apes (gorillas and chims), but also by a diversified avifauna and entomofauna.

The Koboungounda Reserve $(54,457 \mathrm{ha})$ in the urban influence area of the Bertoua city is under threat. The council forest with an area of 59,602 ha. FMUs occupy area of 150,310 ha. Areas of hunting interest with a total area of 86,592 ha 
As pointed out by Kund and Megevand (2013), the development of industrial and artisanal mining in the Congo Basin is competing with other land uses, including forestry and conservation. All these protected areas are threatened by the sometimes clandestine and semimechanized artisanal mining which takes place there, without forgetting the legal logging and the illegal artisanal logging linked to the avatars of the 'mining. These brought the dilemma. Indeed, totaling protected areas yields an area of 505,669.77ha (19.38\%), compared to $1,823,589.66$ ha $(69.89 \%)$ of mining permits; Less than three times the mining permits. Even with the addition of community forests, 645570,62 $(24.74 \%)$ were obtained; Hence a strong threat not to be overlooked. Thus, even if mining appears to be an opportunity, the negative impacts are numerous.

Nevertheless, at the end of the exploration, the company does not wait for the exploitation permit to begin, hence the intensification of deforestation. If it waited, it would have been fixed only on the places where the ore is mined to calculate, unfortunately, the practice at this level is unorthodox. As a result, we realize that conservation and permits occupy 90 to $95 \%$ of the territory of this division, treating other land use activities: agriculture pastures, buildings etc. a great di-lemma and challenge that lead to recurring land use conflicts in this territory.

This paper is the first piece of work to have dealt with field work in an operational and objective manner throughout the Lom \& Djérem. Indeed, the works of Nguepjouo and Manyacka (2008), Tieguhong (2009), Nono (2011), Schwartz et al. (2012); Nodem et al. (2012), Relufa and CED (2014) concern the Boumba \& Ngoko or Kadey division. In addition, the result from Kund and Megevand (2013) deepens the question of the impacts of mining activities in the Congo Basin. These authors also point out that "much of the discourse on conflict minerals rightly emphasizes human rights concerns, but unfortunately, very little extraction takes place in the most important ecosystems on the planet: the Congo Basin.

The geographic information system, remote sensing and use of geospatial tools do not exist in the former research. Of course, we have not forgotten to refine the economic (although official statistics do not exist) and ecological aspects. Our work focuses on employment and income (poverty), forest management, biodiversity management and conservation. It is clear that the land-use maps produced by this study are the first for official statistics in this division, at the very moment when consultations are being held on a master plan for the management and sustainable development of the whole Eastern Region.

\subsection{Some observed problems}

In all the African and Latin American countries where mining is taking place there are a host of problems with the onset of poverty issues at mining sites de-spite positive progress in increasing productivity in the industry. Our research and previous studies highlight contentious issues related to small-scale mining operations and land use conflicts that require urgent attention from regulatory authorities (Akabzaa and Ayamdoo, 2004; Agbesinyale, 2003; Hilson 2002; Songsore et al., 1994). These include: the relationship between small-scale miners and multi-national mining enterprises; land poverty in the mining area; the role of traditional authorities; lack of adequate institutional support; limited opportunities for capital; encroachment on forests and protected areas. It emerges that these issues are deeply rooted in the social and economic circumstances of the small-scale mining sector and can have serious consequences on livelihoods or subsistence as well as mining itself (Kiendrebeogo, 2014).

\subsection{Lessons learned}

In terms of lessons learned, the following deserve to be retained.

Mining activity is highly destructive of the biophysical and socio-economic environment

Extractivism prevails over laws that would benefit from being enforced, re-vised and strengthened,

School wastage and family destructuring are too important to go unnoticed

The failure of planning, the loss of local development and the accentuation of poverty suggest the curse of wealth and the tragedy of the common good.

There is also a stubbornness of populations and extractivist societies, and un-fortunately, populations are poorly trained and poorly equipped, while administrations are equipped to cope with the extractivist powers.

The triumphant extractivism of Cameroon accomplished with the blessing of the investors easies the fall of the authorities in an unorthodox practices under the label of transparency (non-payment of the ad valorem tax, minting of criminal offenses and other abuses).

\section{Conclusion}

Roughly speaking, mining in Cameroon is more than 80 years old. Its modern form comes from the promulgation of a genuine mining code in 2001. At the end of this research, which focused on artisanal mines, one has the right to ask oneself whether to continue this mining adventure? This questioning is in line with that of mining Industries. Extract at any price? Indeed, multi-date and multi-scalar land use change maps have helped to determine the real impacts of mines in the pro-cess of deforestation. In addition, the mapping of the extension of the artisanal and industrial mines of Cameroon makes it possible to situate the overlaps and conflicts of land use recurring.

Consequently, in view of the decline of the forest (32$60 \%$ in 40 years), it seems important to go to suitable solutions, some of which are outlined as a result:

There is a need for zoning, better governance and rigorous planning of mining activities through land-use plans that are based on ultra-high resolution (HHR) images and to be included in local development plans (PDL) or council development plans (PDCs). 
Mining alternatives must be found through incomegenerating activities and, at the same time, awarenessraising and training of mining craftsmen and miners.

Considering the valorization of Protected Areas and the different geotopes through ecotourism and sustainable tourism, it is also possible to reinforce and implement articles 19 and 86 of the mining code on the cost of rehabilitation, without forgetting the inclusion of Payment of ecosystem services in the ad valorem tax. The cost of carbon emissions in exploration and mining must also be calculated and integrated.

Traceability between mining permits and other permits (hunting, UFA forest concessions) to defuse overlapping conflicts. It is necessary to mining ministry (MINMIDT) to supervise the closure of the exploitation bore hole and encourage the systematic reforestation of these sinks.

For local populations, the creation of water points, boreholes and sinks for food and water needs of populations is essential. It should be accompanied by the creation of ponds with filters that serve as a system for recycling water from washing areas before they are discharged into rivers. This can serve to reinforce the resilience of the population.

\section{Acknowledgements}

We are grateful to the GEOFORAFRI Project Manager who has provided us with the necessary funding to carry out this study. Special thanks to all the administrative authorities (Prefect and Sub-Prefect) and institutional (MINIMIDT Divisional Delegate) who in the field have granted us the necessary authorizations to cover the sites, special thanks to all the security forces.

\section{References}

Akabzaa, T. \& Ayamdoo, C. (2004). Increasing the Contribution of Artisanal Mining and Small-Scale Mining to Poverty Reduction Targets: A study of regulatory and institutional framework for artisanal and small-scale mining in Ghana, London: Department for Interna-tional Development.

Eba'a Atyi, R. Lescuyer G., Ngouhouo Poufoun J., Moulendè Fouda T., (2013). Étude de l'importance économique et sociale du secteur forestier et faunique au Cameroun. Rapport Final. CIFOR Bogor 278p.

FAO. (2005). Inventaire forestier national du Cameroun 2003-2004. Rapport final, version préliminaire.

Gartlan S., (1989). La conservation des écosystèmes forestiers au Cameroun. UICN, 186p.

Hilson, G. M. (2002). 'The future of small-scale mining: environmental and socioeconom-ic perspectives', Futures, 34, 863-872.

Kiendrebeogo A. (2014). Contribution de l'étude d'impact de l'exploitation artisanale de l'or sur les moyens d'existence des populations riveraines de la forêt classée de Tiogo dans la région du Centre-Ouest du Burkina Faso. Mémoire de Master Pro. SEN, UYI, Département de Biologie et Physiologie végétales. Yaoundé, 81p.
Kund K. \& Megevand C. (2013). Dynamiques de déforestation dans le bassin du Congo Réconcilier la croissance économique et la protection de la forêt Document de travail $n^{\circ} 4$ Exploitation Minière. $69 p$. 